\title{
Influence of Formulation on Mobility of Clomazone in Soil
}

\author{
Małgorzata Włodarczyk ${ }^{1} \cdot$ Hanna Siwek ${ }^{1}$
}

Received: 4 May 2015/Accepted: 9 August 2016/Published online: 24 August 2016

(c) The Author(s) 2016. This article is published with open access at Springerlink.com

\begin{abstract}
The mobility of clomazone [2-(2-chlorobenzylo)-4,4-dimetylo-1,2-oxazolidin-3-one] in a loamy sand soil and a sand soil was studied in a soil column under laboratory conditions. Commercial clomazone formulation (Command $480 \mathrm{EC}$ ) and clomazone immobilized in an alginate matrix were used for a leaching experiment. For both formulations, the same dose of $2.0 \mathrm{mg}$ of the active substance was applied. After an application of a herbicide, the columns were irrigated with: 100,40 and $3.7 \mathrm{~mm}$ of water. After $1 \mathrm{~h}$, when an addition of water was completed, the soils were sampled in the $5 \mathrm{~cm}$ segments and were used for the analysis of the residues. The use of an alginate formulation reduced the vertical mobility of clomazone into a soil layer in comparison with the formulation EC.
\end{abstract}

Keywords Clomazone - Formulation · Mobility - Soil · Alginate $\cdot$ Column test

Pesticides constitute a significant element of modern agriculture and are mainly used for destroying weeds, controlling pests and fighting plant diseases. However, due to the wide-spread use of pesticides, there has been a great concern about their toxicity towards non-target organisms and the natural environment (Van der Werf 1996; Alister and Kogan 2006; Arias-Estevez et al. 2008). There are various factors which affect pesticide activity in the environment. They can be directly connected with the agricultural production (such as a time, a type and a mode of

Małgorzata Włodarczyk

malgorzata.wlodarczyk@zut.edu.pl

1 Faculty of Environmental Management and Agriculture, West Pomeranian University of Technology in Szczecin, ul. Słowackiego 17, 71-176 Szczecin, Poland the application, a dose), the environmental factors (the atmospheric conditions, a terrain, a type of a soil), the physiochemical properties of an active substance, or a pesticide formulation. Pesticide activity is regulated by a variety of complex, dynamic, physical, chemical and biological processes including sorption - desorption, evaporation, chemical and biological degradation, plant uptake, surface runoff or leaching. These processes determine pesticide mobility in a soil, as well as translocation from a soil to water, air or food (Reddy 1993; El-Nahhal 2003; Sondhia 2009; Urlich et al. 2013). To reduce pesticide pollution, the efforts have been made to improve agricultural pest management, such as developing new biodegradable pesticides, producing the new types of formulations (concentrated in a suspension, granules, the soluble liquids, the ionic liquids) (Mulqueen 2003; Green and Beestman 2007; Knowles 2008; Pernak et al. 2011) as well as formulations based on controlled release (CR) technology (Mogul et al. 1996; Sopeña et al. 2008). CR formulations can regulate or reduce the rate of availability of a pesticide, localizing the chemicals in the crop zone and reducing the amount accessible to leaching processes. The parameters that affect the properties of CR formulation depend on the nature and type of polymer used (Cao et al. 2005; Maqueda et al. 2009; Sopeña et al. 2009; Roy et al. 2014). Several research studies have contributed to the development of formulations for the controlled release in agriculture. Cotterill et al. (1996) found that lignins from the different sources can be used for the matrix formulations, resulting in varying the release rate. The release of pesticides from the lignin matrix depends on the type of the lignin, methods of bonding pesticides in the lignin matrix and the granule size. The CR formulations of isoproturon, imidacloprid and cyromazine have been evaluated by Fernández-Pérez et al. (2011).The effects of two natural 
polymers (alginate and lignin) and two modifying sorbents (bentonite and activated carbon) on the pesticide release kinetics from the CR formulations have been investigated, as well as the mobility of pesticides using the soil columns. The rate of the pesticide release in the soil from the CRFs diminished in all the cases in relation to the technical products. Fernández-Pérez et al. (2000a, b, 2001) showed that the alginate-bentonite CR formulations might constitute the efficient system for reducing atrazine, isoproturon and carbofuran leaching in the layered soil. Moreover, the laboratory tests showed that the modifying agents like anthracite, bentonite, active carbon of the alginate formulations reduce the release rate of chloridazon, metribuzin in comparison with the technical products, and with the alginate formulations without modifying agents (FloresCéspedes et al. 2007). Pepperman and Kuan (1993, 1995) found that the use of linseed oil and alginate as the basis of the CR formulation of alachlor and metribuzin results in reducing the release of the herbicide in comparison with the conventional formulation. The development of $\mathrm{CR}$ formulations of alachlor and atrazine based on ethylcellulose increased their herbicidal activity and reduced the loss by leaching in the soil. In the case of atrazine incorporated in ethylcellulose, matrix modifiers (allophanic clays and nanoclays) had a slight effect on the atrazine release into water, its dissipation and its behavior in the soil compared with the formulation without them (Sopeña et al. 2007; Cea et al. 2010).

The herbicide clomazone [2-(2-chlorobenzylo)-4,4dimetylo-1,2-oxazolidin-3-one] is an isoxazolidinone group of a broad spectrum, a pre-emergence selective herbicide with both a contact and a residual activity which controls the annual broad leaf weeds and grasses. Clomazone is highly water-soluble, minimally volatile, resistant to a hydrolysis under a wide range of $\mathrm{pH}$ values. Clomazone is weakly sorptive to a soil, and its sorption depends on a carbon content. The field dissipation half-life of clomazone, determined from the field studies in the several soil types, ranged from 4 to 16 weeks (Mervosh et al. 1995; Antonious 2000; Lian-Fang et al. 2004; Bhattacharyya et al. 2014). Due to these characteristics, clomazone is persistent in water environment and causes a groundwater contamination. Clomazone residues were detected in the water samples collected from the wells (50\%-70\%) and the rivers $(90 \%)$ in the rice cultivation region (Zanella et al. 2002; Caldas et al. 2010).

The aim of the present study was to determine the influence of the formulation on the mobility of clomazone in the soil.

\section{Materials and Methods}

Two formulations of herbicide clomazone were used in the experiment: emulsifiable concentrate (EC) in the form of a commercial preparation Command $480 \mathrm{EC}$, and in the form of the capsules based on the alginate matrix. The alginate capsules of clomazone were obtained in the Center of Bioimmobilization and Innovative Packaging Materials at the West Pomeranian University of Technology in Szczecin, Poland (Włodarczyk et al. 2010). The active substance with the purity of $99.9 \%$, was provided by Chemical Plant "Organika-Sarzyna", Poland. Selected physical and chemical properties of clomazone are presented in Table 1.

Two soils were used in this experiment. Both soils were taken from Western Pomerania Region, Poland. Soil samples were selected according to their content of the organic carbon and collected at a $0-20 \mathrm{~cm}$ depth, air dried, homogenized and passed through a $2.0 \mathrm{~mm}$ sieve. The physicochemical and granulometrical characteristics of these soils are given in Table 2.

Mobility of clomazone in the soil was tested using PCV columns (ca. $40 \mathrm{~cm}$ long, diameter $\Phi=3.0 \mathrm{~cm}$ ) filled with the air-dry soil. The height of the soil stack in the column was $20 \mathrm{~cm}$, the spraying area was $0.0007 \mathrm{~m}^{2}$. For both formulations, the same dose of $2.0 \mathrm{mg}$ of the active substance was applied. Both herbicide treatments (solution of Command $480 \mathrm{EC} 2.0 \mathrm{mg} \cdot \mathrm{mL}^{-1}$ and alginate capsules $0.056 \mathrm{~g}$ ) were applied to triplicate the soil columns. Then, the columns were irrigated with a dose of water corresponding to the amount of a rainfall characteristic for Western Pomeranian Region, Poland: 100 mm (a maximum rainfall), $40 \mathrm{~mm}$ (an average maximum rainfall) and $3.7 \mathrm{~mm}$ (an average rainfall) (Koźmiński et al. 2012).

Table 1 Selected physical and chemical characteristics of clomazone. http://sitem.herts.ac.uk/aeru/ppdb/en/Reports/168.htm

\begin{tabular}{lll}
\hline Structure diagram & IUPAC Name & 2-(2-chlorobenzylo)-4,4-dimetylo-1,2-oxazolidin-3-one \\
\hline & Physical state & White crystalline solid \\
Chemical formula & $\mathrm{C}_{12} \mathrm{H}_{14} \mathrm{ClNO}_{2}$ \\
& Molecular mass & $239.7 \mathrm{~g} \cdot \mathrm{mol}^{-1}$ \\
& Solubility in water & $1102 \mathrm{mg} \cdot \mathrm{L}^{-1}\left(20^{\circ} \mathrm{C}\right)$ \\
& Octanol/water partition coefficient: & log $\mathrm{K}_{\mathrm{ow}}=2.54$ \\
& & \\
\hline
\end{tabular}


Table 2 Selected properties of soils

\begin{tabular}{|c|c|c|c|c|c|c|c|c|c|}
\hline \multirow[t]{2}{*}{ Soil } & \multirow[t]{2}{*}{ Granulometric group } & \multirow{2}{*}{$\begin{array}{l}\text { Water capacity } \\
(\%)\end{array}$} & \multirow{2}{*}{$\begin{array}{l}\text { Organic carbon } \\
(\%)\end{array}$} & \multicolumn{2}{|l|}{$\mathrm{pH}$} & $\mathrm{Hh}$ & \multirow{2}{*}{ CEC } & \multirow[t]{2}{*}{ TEB } & \multirow{2}{*}{$\begin{array}{l}\text { BS } \\
(\%)\end{array}$} \\
\hline & & & & $\mathrm{H}_{2} \mathrm{O}$ & $\mathrm{KCl}$ & $\left(\mathrm{cmol} \cdot \mathrm{kg}^{-1}\right)$ & & & \\
\hline S1 & Loamy sand soil & 34.63 & 0.83 & 5.56 & 4.28 & 3.33 & 16.10 & 19.43 & 82.88 \\
\hline $\mathrm{S} 2$ & Sand soil & 37.18 & 1.99 & 4.56 & 3.71 & 10.33 & 15.30 & 25.63 & 59.71 \\
\hline
\end{tabular}

$H h$ hydrolytic acidity, $C E C$ cation exchange capacity, $T E B$ total exchangeable bases, $B S$ base saturation

Water was dispensed by a peristaltic pomp with a flow rate of $0.05 \mathrm{~mL} \cdot \mathrm{min}^{-1}$. Having completed the application of water $(24 \mathrm{~h}$ ), after one extra hour (to minimize the degradation process) the content of the column was divided into the 5-centimeter pieces, for which the active substance concentration were determined $(0-5 \mathrm{~cm}$ layer I, 5-10 cm layer II, $10-15 \mathrm{~cm}$ layer III, $15-20 \mathrm{~cm}$ layer IV). In the case of the maximum rainfall, the water elutes (layer $\mathrm{V}$ ) collected during the experiment were made a subject to an extraction too.

The wet soil samples were extracted with $75 \mathrm{~mL}$ of acetone. The samples were shaken for $4 \mathrm{~h}$ in a mechanical shaker and then filtered. Next, acetone was evaporated in a rotary vacuum evaporator $\left(35^{\circ} \mathrm{C}\right)$ and the residues (water samples) were liquid-liquid extracted with chloroform. Extracts were dehydrated with anhydrous sodium sulfate, purified on the columns filled with florisil and anhydrous $\mathrm{Na}_{2} \mathrm{SO}_{4}$ and evaporated to a minimum volume $(2.0 \mathrm{~mL})$ for the analysis. The water elutes (fraction $\mathrm{V}$ ) were liquid-liquid extracted with chloroform, dehydrated with anhydrous sodium sulfate and evaporated to a minimum volume $(2.0 \mathrm{~mL})$ for the analysis. The recovery of clomazone was determined by fortification of the soil samples at the concentration $0.01,0.1,1.0 \mathrm{mg} \cdot \mathrm{kg}^{-1}$, and the water samples at the concentration $0.01,0.1,1.0 \mathrm{mg} \cdot \mathrm{mL}^{-1}$ in three replicates. The average recovery of clomazone for the soil samples was $93 \%$, for the water samples $96 \%$. The quantification limit of the method for the soil samples was $0.0005 \mathrm{mg} \cdot \mathrm{kg}^{-1}$, for the water samples was $0.00025 \mu \mathrm{g} \cdot \mathrm{mL}^{-1}$. The standard solutions of clomazone at the concentrations from 0.0005 to $0.01 \mathrm{mg} \cdot \mathrm{mL}^{-1}$ were prepared in chloroform.

Gas chromatography was used to determine the concentrations of clomazone. PerkinElmer Clarus 600 gas chromatograph was equipped with a MS detector and Elite $5 \mathrm{MS}$ column $(30 \mathrm{~m} \times 0.25 \mathrm{~mm}, 0.5 \mu \mathrm{m}$ film thickness $)$. The operating temperatures were: detector $320^{\circ} \mathrm{C}$, oven temperature $100^{\circ} \mathrm{C}-1 \mathrm{~min}, 10^{\circ} \mathrm{C} \cdot \mathrm{min}^{-1}$ to $220^{\circ} \mathrm{C}-5 \mathrm{~min}$, $25^{\circ} \mathrm{C} \cdot \mathrm{min}^{-1}$ to $300^{\circ} \mathrm{C}-2 \mathrm{~min}$. The carrier gas was helium with a flow rate of $1.0 \mathrm{~mL} \cdot \mathrm{min}^{-1}$. Under these conditions the retention time was $13.02 \mathrm{~min}$. To determine clomazone in the samples, the electronic ionization method, type EI+, was used. Clomazone qualitative analysis was based on the mass spectrum and ions: 125, 204, 239 which are characteristic for this compound. Quantitative analysis was performed by the comparative method, based on the calibration curve $\left(\mathrm{y}=80491 \mathrm{x}-26.13 ; \mathrm{n}=6, \mathrm{R}^{2}=0.999\right)$.

All experimental data was calculated using statistical program Statistica 10.0 for Windows. Statistical analyses were performed using two-way analysis of variance (ANOVA) to determinate the formulation and the soil type effect on the mobility of clomazone in the soil. Means were compared by Tukey test and expressed as mean \pm SD. The differences were considered to be significant at a significance level $p=0.05$.

\section{Results and Discussion}

The results of the research indicate a significant relationship between the formulation and the mobility of clomazone in the soil. In the case of the emulsifiable concentrate formulation (Command EC), the irrigation with a water amount corresponding to the maximum rainfall $(100 \mathrm{~mm})$ resulted in a distribution of clomazone to each layer under the analysis. Similar relationship was found both for the loamy sand soil S1 as well as the sand soil S2 (Fig. 1). The highest concentration of clomazone was determined in the layer II at the depth of 5-10 cm: for S1 $60.76 \% \pm 8.17 \%$, and for S2 $58.32 \% \pm 7.87 \%$ of the applied dose. In both soils, the significant amounts of clomazone were also found in the layers: I, III and IV. The concentration of clomazone determined in the layers $\mathrm{V}$ (leachate) were insignificant $(<1 \%)$. The statistical analysis conducted with the use of Tukey's test ( $p=0.05$ ) reveal the significant difference in the concentration of clomazone, between S1 and S2 only in the layer III. Irrigation with the amount of water corresponding to the average maximum rainfall $(40 \mathrm{~mm})$ resulted in the translocation of the herbicide in the EC formulation in soil. In both soil types, the highest concentration of the active substance was determined in the first two layers at the depth of $0-10 \mathrm{~cm}$. The variation in the content of clomazone in the layers I and II of the loamy sand soil (S1) was significant and amounted to $54.55 \% \pm 6.92 \%$ (layer I) and $33.79 \% \pm 5.93 \%$ (layer II). The translocation of clomazone in the sand (S2) was found to be significantly greater, and the highest concentration of the herbicide was determined for the layer II as a result of its translocation from the layer I. The content of the active substance in the layer I was 
Fig. 1 Mobility of clomazone as formulation EC in soil

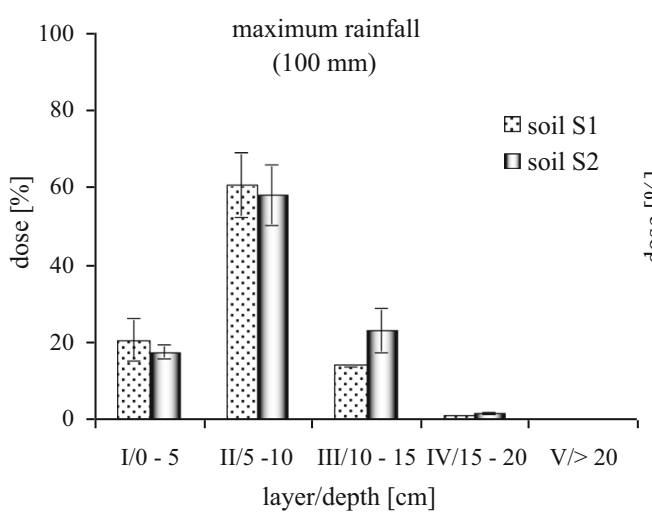

$41.75 \% \pm 0.06 \%$, and in the layer II $49.85 \% \pm 7.08 \%$. However, the differences between the two layers of S2 were not statistically significant. In the case of the average maximum rainfall $(40 \mathrm{~mm})$, the significant concentration of clomazone was also determined in the layer III at the depth of $10-15 \mathrm{~cm}(\mathrm{~S} 1=2.30 \% \pm 0.49 \%, \mathrm{~S} 2=1.03 \% \pm$ $0.12 \%$ ), whereas in the layer IV the concentration did not exceed $1 \%$ of the applied dose. The variation in clomazone mobility as recorded in S1 and S2 soil types were found to be statistically significant, as was confirmed by the results of the Tukey's test $(p=0.05)$. The amount of water corresponding to the average rainfall $(3.7 \mathrm{~mm})$ did not significantly affect the translocation of clomazone in the soil as applied in the form of the commercial preparation Command $480 \mathrm{EC}$, since the applied dose of water did not translocate below the first analysed layer of the soil in the column, $0-5 \mathrm{~cm}$ (data not shown on figure). The application of the formulation based on sodium alginate caused a significant decrease in clomazone mobility in the soil. Regardless of the applied dose of water, the highest concentration of clomazone, ranging from $63.50 \%$ to $100 \%$, was determined in the layer I at the depth of $0-5 \mathrm{~cm}$. In the case of the maximum rainfall, clomazone released from the alginate matrix
$(\mathrm{S} 1=27.30 \% \pm 0.83 \% ; \mathrm{S} 2=24.43 \% \pm 1.45 \%)$ was distributed mainly to the layers II and III. Both, in the case of $\mathrm{S} 1$ as well as S2, concentration of clomazone was determined at the depth of 5-10 cm (II) where it amounted to approximately $18 \%$, and at the depth of $10-15 \mathrm{~cm}$ (III) where the concentration was $7.57 \%$ in $\mathrm{S} 1$ and $4.36 \%$ in $\mathrm{S} 2$. In the layer IV $(15-20 \mathrm{~cm})$ and V (leachate $>20 \mathrm{~cm})$, concentration of the analysed active substance was below $1 \%$ (Fig. 2). In the case of the average maximum rainfall, clomazone released from the alginate matrix $(\mathrm{S} 1=15.20 \% \pm$ $1.82 \%, \mathrm{~S} 2=8.35 \% \pm 0.95 \%$ ) translocated into the soil at the depth of $5-10 \mathrm{~cm}$. Concentration of clomazone $>1 \%$ was not found below the layer II. For the maximum $(100 \mathrm{~mm})$ and the average maximum rainfall $(40 \mathrm{~mm})$ the differences in the migration of clomazone immobilized in the alginate matrix in the soils $\mathrm{S} 1$ and $\mathrm{S} 2$ were not statistical significant according to Tukey's test at $p=0.05$. As it was the case with EC formulation, the average rainfall had no effect on the mobility of clomazone, as the applied dose of water did not reach below the first analysed layer of the soil, 0-5 cm (data not shown on figure). On the basis of the results of the experiment, it was found that the differences in the mobility of clomazone applied in the form of Command
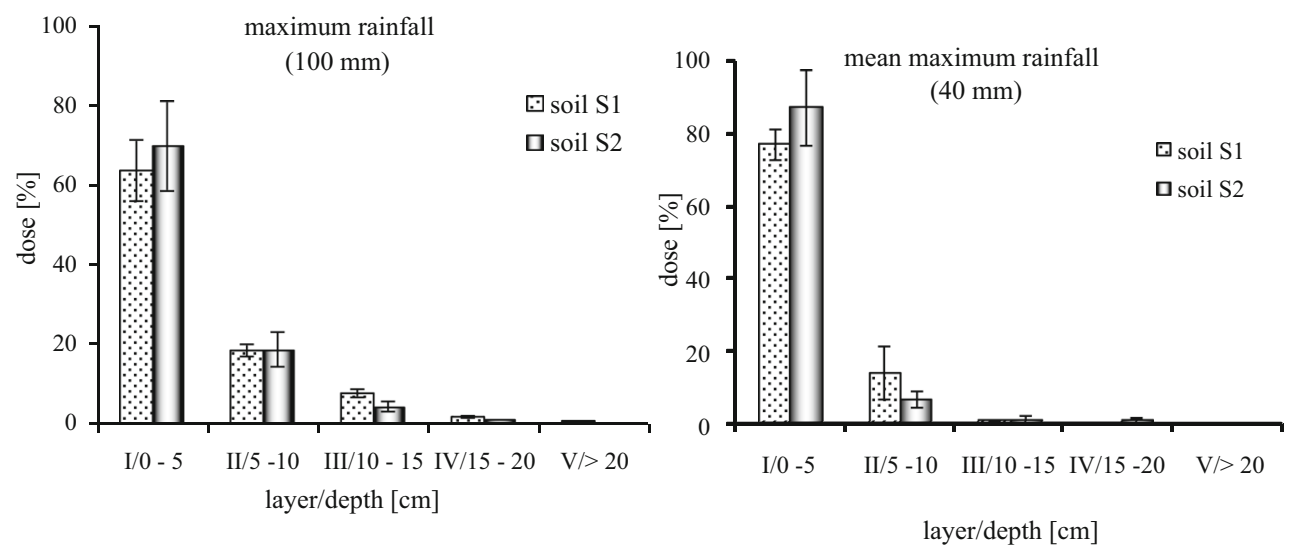

Fig. 2 Mobility of clomazone immobilized in alginate matrix in soil 
480 EC preparation and alginate capsules are significant which was additionally verified with the use of Tukey's test at $p=0.05$.

Pesticide leaching through the soil is a particularly important issue in a number of environmental and agronomic problems. Leaching is considered to be the main cause of groundwater contamination with pesticides which is largely determined by physiochemical properties of the active substances, soils (mechanical composition, organic matter, soil moisture, $\mathrm{pH}$ ) and rainfall.

As can be concluded on the grounds of the results of the experiment, the formulation has a significant effect on the mobility of clomazone in soil. Additional factor which affects the process is the amount of precipitation (the dose of water applied). In the case of clomazone, the soil properties did not affect its mobility in a significant way. Clomazone in the form of EC formulation is more prone to leaching than when it is immobilized in the alginate matrix. Primarily, the fact can be attributed to the high solubility of clomazone in water (Table 1) and a relatively weak adsorption in soil $\left(\mathrm{K}_{\mathrm{d}}=0.47-5.30\right)$. The values of the leaching potential LP (Fernández-Pérez et al. 2011), calculated on the basis of half-life time (DT50 in soil 28-117 days) and partition coefficient values $\mathrm{K}_{\mathrm{OC}}\left(150-300 \mathrm{~mL} \cdot \mathrm{g}^{-1}\right)$ as specified in the literature on the subject (Antonious 2000; Lian-Fang et al. 2004), indicates that clomazone is a substance characterized by its high lechability properties ( $\mathrm{LP}=2.2-5.1)$.

$L P=\log \left(D T 50_{\text {soil }}\right) \cdot\left(4-\log \left(K_{O C}\right)\right)$

Consequently, clomazone presents properties, which indicate a groundwater contamination potential. The results of the monitoring studies of aqueous environment by Caldas et al. (2010) additionally acknowledge this fact. Residues of clomazone in the range of $0.20-0.82 \mu \mathrm{g} \cdot \mathrm{L}^{-1}$ were found in water collected from $70 \%$ of analysed wells.

The formulation based on the alginate matrix, that was used in our studies significantly reduces clomazone mobility in the soil profile. The release rate of clomazone from capsules in the soil was slower than in water. Values $\mathrm{T}_{50}$ (a release time of $50 \%$ of active substance from the matrix) for clomazone in water was: for hydrogel capsules 1.09-1.34 h, for dry capsules 2.30-2.31 h (Włodarczyk and Siwek 2013). In soil this process is regulated by the applied dose of water (a rainfall in the natural conditions) and the amount of the active substance released from matrix, distribution of which depends on the physiochemical properties of soil.

The additional factors affecting on the kinetics of clomazone release from the alginate matrix to soil, and thus its mobility, is the occlusion of the alginate matrix surface by the soil particles and the slower diffusion of the active substance from the matrix in soil. Moreover, the substances contained in the soil solution may delay the translocation of the active substances to the aqueous phase (FernándezPérez et al. 2000b). The same relationship was obtained by studying the impact of the formulation on the mobility of pendimethalin and metazachlor in the soil. Pendimethalin and metazachlor, as commercial formulations Panida 330 EC and Metazachlor 500 SC, have the ability to move in the soil. The use of herbicides immobilized in the alginate matrix, reduce this process (Włodarczyk 2014). Additional technology which affects the behavior of herbicides in the environment is an adjuvants technology. Numerous studies show that adjuvants strongly influence pesticide delivery, uptake, redistribution, persistence and the final biological performance (Krogh et al. 2003). Research indicates also that adjuvants can reduce leaching of herbicides in the soil (Kucharski and Sadowski 2011).

The results of the current study demonstrated the capacity of formulation based on the CR technology to control the delivery of pesticides with high water solubility, thereby reducing the amount of active ingredients which leach, and thus indicating its useful application to prevent pollution of water environment.

Acknowledgments Acknowledgement for Chemical Plant "OrganikaSarzyna", Poland, for providing the active substance for the experiment. The chromatograph Clarus 600 by PerkinElmer was purchased within the framework of a Project No. OR16-61535-OR1600021/07 under the Sectoral Operational Programme of "Fisheries and Fish Processing 2004-2006". The research was conducted within the framework of a Grant of the Ministry of Science and Higher Education, Poland No. NN 305151433.

Open Access This article is distributed under the terms of the Creative Commons Attribution 4.0 International License (http://creative commons.org/licenses/by/4.0/), which permits unrestricted use, distribution, and reproduction in any medium, provided you give appropriate credit to the original author(s) and the source, provide a link to the Creative Commons license, and indicate if changes were made.

\section{References}

Alister C, Kogan M (2006) ERI: environmental risk index. A simple proposal to select agrochemicals for agricultural use. Crop Prot 25:202-211

Antonious GF (2000) Clomazone residues in soil and runoff: measurement and mitigation. Bull Environ Contam Toxicol 64:168-175

Arias-Estevez M, Lopez-Periago E, Martinez-Carballo E, SimalGandara J, Mejuto JC, Garcia-Rio L (2008) The mobility and degradation of pesticides in soils and the pollution of groundwater resources. Agric Ecosyst Environ 123:247-260

Bhattacharyya A, Ghosh B, Das SP (2014) Degradation dynamics of clomazone in paddy field. J Crop Weed 10(2):392-396

Caldas SS, Demoliner A, Costa FP, D'Oca MGM, Primel EG (2010) Pesticide residue determination in groundwater using solid-phase extraction and high-performance liquid chromatography with diode array detector and liquid chromatography-tandem mass spectrometry. J Braz Chem Soc 21:642-650

Cao Y, Huang L, Chen J, Liang J, Long S, Lu Y (2005) Development of a controlled release formulation based on a starch matrix system. Int J Pharm 298:108-116 
Cea M, Cartes P, Palma G, Mora ML (2010) Atrazine efficiency in an andisol as affected by clays and nanoclays in ethylcellulose controlled release formulations. R C Suelo Nutr 10(1):62-77

Cotterill JV, Wilkins RM, Silva FT (1996) Controlled release of diuron from granules based on lignin matrix system. J Control Release 40:133-142

El-Nahhal Y (2003) Persistence, mobility, efficacy and activity of chloroacetanilide herbicide formulation under greenhouse and field experiments. Environ Pollut 124(1):33-38

Fernández-Pérez M, Villafranca-Sánchez M, González-Pradas E, Martinez-López F, Flores-Céspedes F (2000a) Controlled release of carbofuran from an alginate-bentonite formulation: water release kinetics and soil mobility. J Agric Food 48(3):938-943

Fernández-Pérez M, González-Pradas E, Villafranca-Sánchez M, Flores-Céspedes F (2000b) Mobility of isoproturon from an alginate-bentonite controlled release formulation in layered soil. Chempsphere 41:1495-1501

Fernández-Pérez M, González-Pradas E, Villafranca-Sánchez M, Flores-Céspedes F (2001) Mobility of atrazine from alginatebentonite controlled release formulations in layered soil. Chemosphere 43(3):347-353

Fernández-Pérez M, Garrido-Herrera FJ, González-Pradas E (2011) Alginate and lignin-based formulations to control pesticides leaching in a calcareous soil. J Hazard Mater 190:794-801

Flores-Céspedes F, Villafranca-Sánchez M, Pérez-Garcia S, Fernández-Pérez M (2007) Modifying sorbents in controlled release formulations to prevent herbicides pollution. Chemosphere 69:785-794

Green JM, Beestman GB (2007) Recently patented and commercialized formulation and adjuvant technology. Crop Prot 26:320-327

Knowles A (2008) Recent developments of safer formulations of agrochemicals. Environmentalist 28:35-44

Koźmiński Cz, Michalska B, Czarnecka M (2012) The climate of West Pomeranian region. Zapol Dmochowski, Sobczyk Production and Trading Company, Szczecin

Krogh KA, Halling-Sørensen B, Mogensen BB, Vejrup KV (2003) Environmental properties and effects of nonionic surfactant adjuvants in pesticides: a review. Chemosphere 50(7):871-901

Kucharski M, Sadowski J (2011) Behavior of metazachlor applied with additives in soil: Laboratory and field studies. J Food Agric Environ 9(3,4):723-726

Lian-Fang L, Guo-Xue L, Ren-Bin Y, Zheng-Yuan G, Xiao-Yong L (2004) Clomazone dissipation, adsorption and translocation in four paddy topsoils. J Environ Sci 16(4):678-682

Maqueda C, Partal P, Villaverde J, Pérez-Rodriguez JL (2009) Characterization of sepiolite-gel-based formulations for controlled release of pesticides. Appl Clay Sci 46:289-295

Mervosh TL, Sims GK, Stoller EW (1995) Clomazone fate in soil as affected by microbal activity, temperature and soil moisture. J Agric Food Chem 43:537-543
Mogul MG, Akin H, Hasirci N, Trantolo DJ, Gresser JD, Wise DL (1996) Controlled release of biologically active agents for purposes of agricultural crop management. Resour Conserv Recycl 16:289-320

Mulqueen P (2003) Recent advances in agrochemical formulation. Adv Colloid Interface 106:83-107

Pepperman AB, Kuan JW (1993) Slow release formulations of metribuzin based on alginate-kaolin-linseed oil. J Control Release 26:21-30

Pepperman AB, Kuan JW (1995) Controlled release formulations of alachlor based on calcium alginate. J Control Release 34:17-23

Pernak J, Syguda A, Janiszewska D, Materna K, Praczyk T (2011) Ionic liquids with herbicidal anions. Tetrahedron 67:4838-4844

Reddy KN (1993) Effect of acrylic polymer adjuvants on leaching of bromacil, diuron, norfurazon and simazine in soil columns. Bull Environ Contam Tox 50:449-457

Roy A, Singh SK, Bajpai JB, Bajpai AK (2014) Controlled pesticide release from biodegradable polymers. Cent Eur J Chem 12:453-469

Sondhia S (2009) Leaching behavior of metsulfuron in two texturally different soil. Environ Monit Assess 154:111-115

Sopeña F, Cabrera A, Maqueda C, Morillo E (2007) Ethylcellulose formulations for controlled release of the herbicide alachlor in a sandy soil. J Agric Food Chem 22:8200-8205

Sopeña F, Morillo E, Villaverde J, Maqueda C (2008) Reduction of pesticide pollution in agricutural soils by using controlled release formulations: efficacy and persistence studies. Fresen Environ Bull 17(10b):1705-1710

Sopeña F, Maqueda C, Morillo E (2009) Controlled release formulations of herbicides based on micro-encapsulation. Cien Investig Agric 35(1):27-42

Urlich U, Dietrich A, Fohrer N (2013) Herbicide transport via surface runoff during intermittent artificial rainfall: a laboratory plot scale study. Catena 101:38-49

Van der Werf HMG (1996) Assessing the impact of pesticides on the environment. Agric Ecosyst Environ 60:81-96

Włodarczyk M (2014) Influence of formulation on mobility metazachlor in soil. Environ Monit Assess 86:3503-3509

Włodarczyk M, Siwek H (2013) Clomazone release kinetics from alginate matrix to the water environment. Przem Chem 92(8):1513-1516

Włodarczyk M, Siwek H, Bartkowiak B, Muszyńska A (2010) Optymalization of production and characterization of hydrogel microcapsules with controlled release of selected herbicides. Przem Chem 48(4):582-586

Zanella R, Primel EG, Machado SLO, Gonçalves FF, Marchezan E (2002) Monitoring of the herbicide clomazone in environmental water samples by solid-phase extraction and high-performance liquid chromatography with ultraviolet detection. Chromatography 55(9-10):573-577 